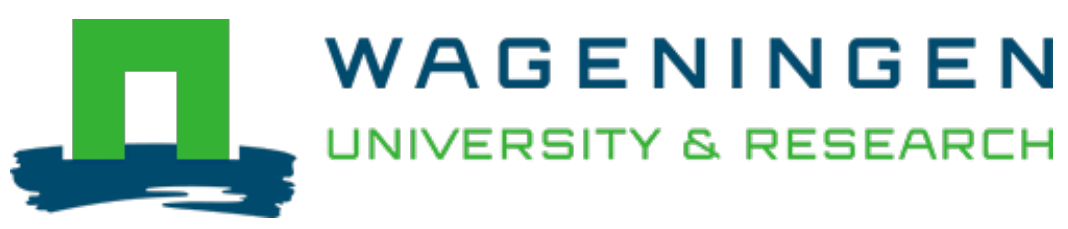

\title{
Dough quality of bread wheat lacking $i$-gliadins with celiac disease epitopes and addition of celiac-safe avenins to improve dough quality
}

\author{
Journal of Cereal Science \\ Broeck, H.C.; Gilissen, L.J.W.J.; Smulders, M.J.M.; Meer, I.M.; Hamer, R.J. \\ https://doi.org/10.1016/j.jcs.2010.12.004
}

This article is made publicly available in the institutional repository of Wageningen University and Research, under the terms of article $25 \mathrm{fa}$ of the Dutch Copyright Act, also known as the Amendment Taverne. This has been done with explicit consent by the author.

Article 25 fa states that the author of a short scientific work funded either wholly or partially by Dutch public funds is entitled to make that work publicly available for no consideration following a reasonable period of time after the work was first published, provided that clear reference is made to the source of the first publication of the work.

This publication is distributed under The Association of Universities in the Netherlands (VSNU) 'Article $25 \mathrm{fa}$ implementation' project. In this project research outputs of researchers employed by Dutch Universities that comply with the legal requirements of Article $25 \mathrm{fa}$ of the Dutch Copyright Act are distributed online and free of cost or other barriers in institutional repositories. Research outputs are distributed six months after their first online publication in the original published version and with proper attribution to the source of the original publication.

You are permitted to download and use the publication for personal purposes. All rights remain with the author(s) and / or copyright owner(s) of this work. Any use of the publication or parts of it other than authorised under article $25 \mathrm{fa}$ of the Dutch Copyright act is prohibited. Wageningen University \& Research and the author(s) of this publication shall not be held responsible or liable for any damages resulting from your (re)use of this publication.

For questions regarding the public availability of this article please contact openscience.library@,wur.nl 


\title{
Dough quality of bread wheat lacking $\alpha$-gliadins with celiac disease epitopes and addition of celiac-safe avenins to improve dough quality
}

\author{
Hetty C. van den Broeck ${ }^{\mathrm{a}, *}$, Ludovicus J.W.J. Gilissen ${ }^{\mathrm{a}}$, Marinus J.M. Smulders ${ }^{\mathrm{a}}$, Ingrid M. van der Meer ${ }^{\mathrm{a}}$, \\ Rob J. Hamer ${ }^{\text {b }}$ \\ a Plant Research International, Wageningen UR, P.O. Box 16, 6700 AA Wageningen, The Netherlands \\ ${ }^{\mathrm{b}}$ Laboratory of Food Chemistry, Wageningen UR, P.O. Box 8129, 6700 EV Wageningen, The Netherlands
}

\section{A R T I C L E I N F O}

\section{Article history:}

Received 14 July 2010

Received in revised form

3 November 2010

Accepted 14 December 2010

\section{Keywords:}

Celiac disease

Bread wheat

Chinese Spring deletion lines

Dough properties

Gliadins

Oat avenins

\begin{abstract}
A B S T R A C T
Celiac disease is a T-cell mediated immune response in the small intestine of genetically susceptible individuals caused by ingested gluten proteins from wheat, rye, and barley. In the allohexaploid bread wheat (Triticum aestivum), gluten proteins are encoded by multigene loci present on the homoeologous chromosomes 1 and 6 of the three homoeologous genomes A, B, and D. The effect of deleting individual gluten loci was analyzed in a set of deletion lines of T. aestivum cv. Chinese Spring with regard to the level of T-cell stimulatory epitopes (Glia- $\alpha 9$ and Glia- $\alpha 20$ ) and to technological properties of the dough including mixing, stress relaxation, and extensibility.

Deletion of loci encoding $\omega$-gliadins, $\gamma$-gliadins, and LMW-glutenins located on the short arm of chromosome 1D, reduced the number of T-cell stimulatory epitopes and caused minor deterioration of dough quality by increase of elasticity. Deletion of loci encoding $\alpha$-gliadins located on the short arm of chromosome 6D, resulted in a significant decrease in T-cell stimulatory epitopes. In parallel, the dough became more stiff and less elastic, which is an improvement for 'Chinese Spring' dough.

We demonstrated that $\alpha$-gliadins from wheat can largely be compensated by addition of avenins from oat to the flour to meet technological requirements.
\end{abstract}

(c) 2011 Elsevier Ltd. All rights reserved.

\section{Introduction}

Dough quality for bread making highly depends on the presence and composition of wheat gluten proteins. These gluten proteins are composed of monomeric gliadins and polymeric glutenins, which together determine the bread-making quality (Branlard et al., 2001; Shewry et al., 1997). Glutenins are responsible for the elastic properties of the dough, whereas the gliadins are responsible for the viscous properties. High molecular weight glutenin subunits (HMW-GS) and low molecular weight glutenin subunits (LMW-GS) can form large polymers by inter-molecular disulfide bonds. The LMW-GS can be divided in typical LMW-GS B-subunits that can act as chain extenders because of their ability to form inter-molecular disulfide bonds and in gliadin-like LMW-GS C- and D-subunits that can act as chain terminators because they lack the ability of forming several inter-molecular disulfide bonds (D'Ovidio and Masci, 2004). The amount of large glutenin macro polymers (GMP) is an important quality parameter and strongly relates to dough properties (Don et al., 2003; Gupta et al.,

\footnotetext{
* Corresponding author. Tel.: +31 317 480974; fax: +31 317418094

E-mail address: hetty.busink@wur.nl (H.C. van den Broeck).
}

1996; Popineau et al., 1994; Singh et al., 1990; Weegels et al., 1996). Gliadins can be divided into $\alpha / \beta-, \gamma-$, and $\omega$-gliadins (Woychik et al., 1961) which have specific water-retaining capacities important for dough viscosity.

In bread production, the dough mixing process (i.e. the controlled addition of water to the wheat flour) is a very important step (Millar, 2006; Skerritt et al., 1996; Weegels et al., 1996). During mixing, the gluten proteins are rehydrated and homogenously distributed throughout the dough. Upon resting, a three-dimensional gluten network structure is formed that will determine the viscoelastic and gas-holding properties of the dough. Detailed mixing and rheological studies have revealed a direct relationship between gluten composition and structural and dough properties (for a review see Hamer et al., 2009). For example, the ratio between glutenins and gliadins is especially relevant for the viscous vs. elastic properties of dough. A high ratio of monomeric vs. polymeric proteins will lead to a less stiff and more viscous dough (Song and Zheng, 2007, and references therein).

Apart from their role in dough quality, gluten proteins can affect health in genetically susceptible individuals. Many gluten proteins contain T-cell stimulatory epitopes that can cause celiac disease (CD; gluten intolerance) (Sollid, 2002). After consumption of gluten 
A

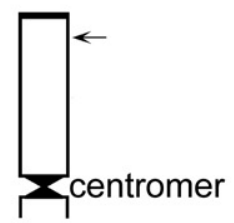

1AS-3

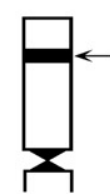

1DS-5

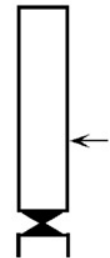

6AS-1

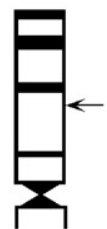

6DS-2

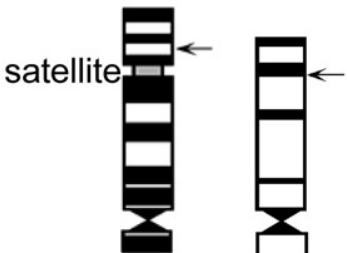

1BS-19/6DS-4

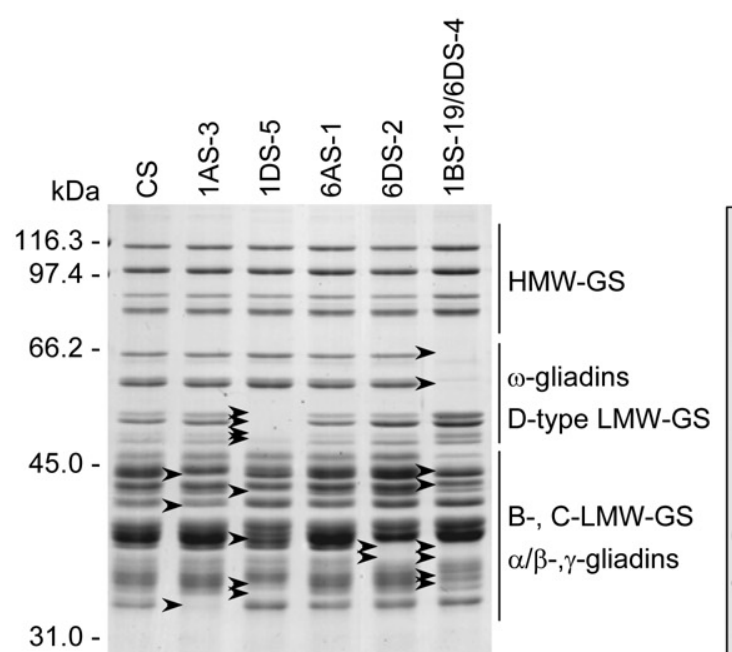

B

\section{E}
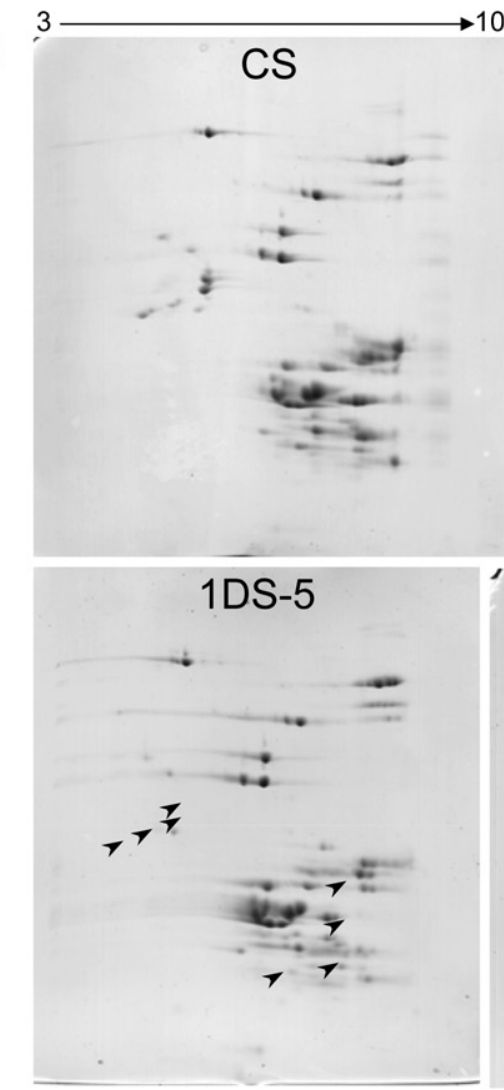

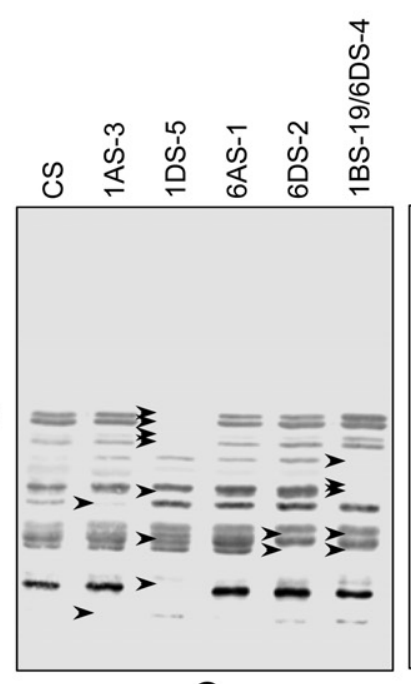

C
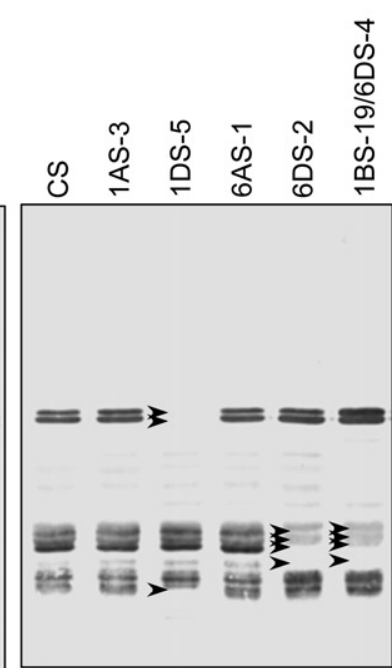

D

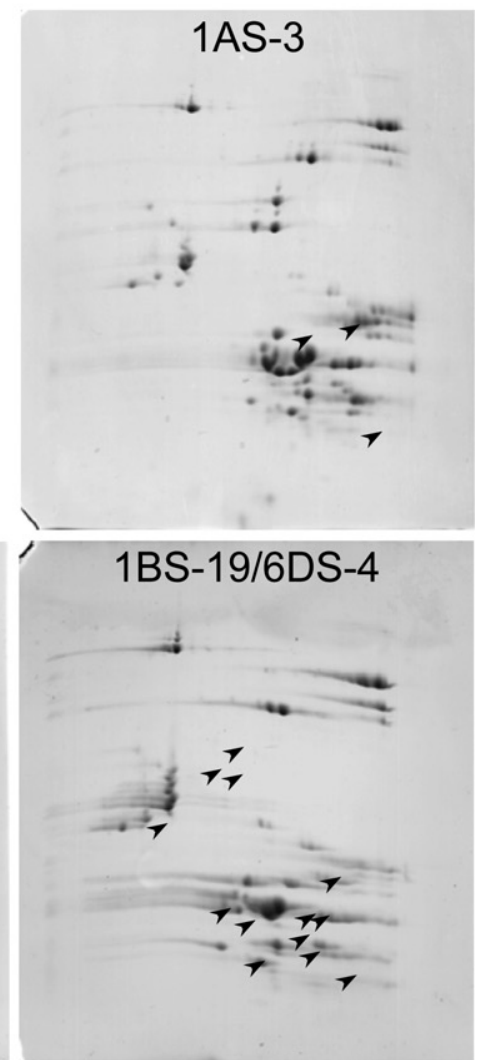

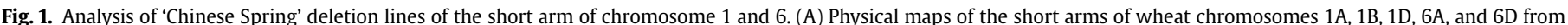

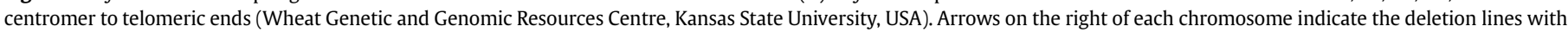

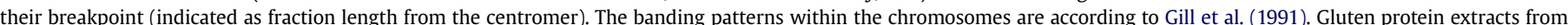

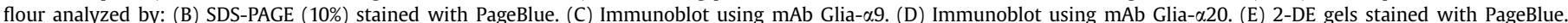
CS: Chinese Spring wild type. Arrow heads indicate absent gluten protein bands. 
proteins from wheat, rye, or barley, the epitopes trigger an immune response that causes damage to the small intestine. CD-patients are therefore restricted to a lifelong gluten-free diet. About $1 \%$ of the general population suffers from $\mathrm{CD}$. A doubling of the prevalence of $\mathrm{CD}$ in Finland in the last two decades is described by Lohi et al. (2007), which could not be ascribed to improved detection only. The numbers are increasing not only because of better diagnosis but also because of increased intake and usage of wheat constituents as food additives (Atchison et al., 2010; Day et al., 2006). Among the different gluten epitopes that have been identified, the $\alpha$-gliadin epitopes are considered the most immunogenic (Arentz-Hansen et al., 2000a,b, 2002; Camarca et al., 2009; Janatuinen et al., 2002; Maiuri et al., 2003; Molberg et al., 2003; Schuppan et al., 2003; Vader et al., 2002) of which the Glia- $\alpha 9$ is a major immunodominant epitope. The Glia- $\alpha 9$ epitope sequence $(\alpha \mathrm{I})$ is part of the proteolytic resistant 33-mer identified by Shan et al. (2002, 2005) that has a high T-cell stimulatory effect. The 33-mer sequence (LQLQPFPQPQLPYPQPQLPYPQPQLPYPQPQPF) is only present in $D$-genome protein sequences of $\alpha / \beta$-gliadins (Salentijn, personal communication).

Gluten proteins are encoded by 15 major loci. The HMW-GS are encoded by Glu-1 loci on the long arm of group 1 chromosomes (Glu$A 1,-B 1$, and -D1) (Harberd et al., 1986). The LMW-GS are encoded by the Glu-3 loci on the short arms of group 1 chromosomes (Glu-A3, $-B 3$, and $-D 3$ ) (Singh and Shepherd, 1988) and are tightly linked to the loci encoding the $\gamma$ - and $\omega$-gliadins (Gli-A1, -B1, and -D1 and Gli-A3, $-B 3$, and $-D 3$ ). Most $\alpha / \beta$-gliadins are encoded by loci on the short arms of group 6 chromosomes (Gli-A2, B2, and D2) (Marino et al., 1996). The $\alpha$-gliadins encoded by chromosome 6D contain the most epitopes and in the highest frequencies (Van Herpen et al., 2006). Although differences exist in relative amounts of epitopes among wheat cultivars (Molberg et al., 2005; Salentijn et al., 2009; Spaenij-Dekking et al., 2005; Van den Broeck et al., 2010a,b), it may be difficult to find a tetraploid durum wheat or a hexaploid bread wheat variety that is completely safe for CD-patients. Therefore, other strategies also need to be explored.

Deletion lines of Triticum aestivum cv. Chinese Spring (CS) were selected having specific deletions on the short arms of group 1 and 6 chromosomes and generally lacking one of the three homoeologous loci encoding gluten proteins (Endo and Gill, 1996; Qi et al., 2003). In a previous study, Van den Broeck et al. (2009b) identified deletion lines that had a reduced content of T-cell stimulatory $\alpha$-gliadin epitopes, Glia- $\alpha 9$ and Glia- $\alpha 20$. However, removing gliadins changes dough technological properties, notably causing an increase in stiffness of the dough. In the present study, we aimed to characterize the effects on dough properties more extensively for the most promising deletion lines, i.e., the lines with the shortest deletion that gave the largest reduction in T-cell stimulatory epitope content. To investigate whether it is possible to compensate for the change in dough technological properties, we tested the effects of adding oat avenins to dough of the selected deletion lines. A few CD-patients have been described that respond to oat avenins. These patients are, however, very sensitive and form a minority of the CD-patients. Oat avenins are related to wheat gliadins, but are generally considered to be safe for CD-patients (Pulido et al., 2009 and references therein).

\section{Material and methods}

\subsection{Plant material}

From the Wheat Genetic \& Genomic Resources Center (WGGRC) Kansas State University, USA (http://www.k-state.edu/wgrc/Germp lasm/Deletions/del_index.html), seeds were obtained from $T$. aestivum Chinese Spring (CS) deletion lines 1AS-3, 1DS-5, 6AS-1, 6DS-2
(/5BS-1), and 1BS-19/6DS-4 as described (Endo and Gill, 1996; Gill et al., 1991; Qi et al., 2003). The deletion lines had partial deletions of the short arms of chromosomes 1 and 6 , which were characterized by cytogenetics (Fig. 1A). Deletion line 6AS-1 was marked as being probably heterozygous. Seeds of CS wild type (wt) (CGN04086) were obtained from the Centre for Genetic Resources (CGN), the Netherlands (http://www.cgn.wur.nl/uk/). Plants of CS wt (CGN04086) and deletion lines were grown in a climatized greenhouse and seeds were harvested at maturity. Ears of deletion lines 1AS-3 and 6AS-1 looked similar as CS wt. Ears of deletion lines 1DS-5, 6DS-2(/5BS-1), and 1BS-19/6DS-4 were only half filled with grains at maturity. Analysis of these deletion lines is also described in Van den Broeck et al. (2009b). However, new rounds of seed multiplications have been performed to obtain sufficient amounts of seeds. This might have caused differences in flour properties and might explain differences in results obtained for mixing, extension testing and glutenin macro polymer volume.

\subsection{Milling}

Grain samples were milled using a Quadrumat JR laboratory mill (Brabender, Germany) according to Approved Method 26-50 (AACC, 1995). Prior to milling, kernel moisture was adjusted to $15 \%$ by incubation on a roller bank overnight at room temperature. Bran was separated from endosperm flour by sieving through mesh $(150 \mu \mathrm{m})$. After sieving, the flour yield ranged from 34 to $47 \%$. These flour samples were used for mixing experiments and rheology experiments. Commercial oat flakes (De Halm, The Netherland) were ground in an analytical mill (A 11 Basic, IKA-Werke) and sieved through mesh $(315 \mu \mathrm{m})$.

\subsection{Total protein content in flour}

The total nitrogen content of the flour ( $\mathrm{N} \times 5.7$ for wheat and $\mathrm{N} \times 6.26$ for oat) (Flander et al., 2007) was calculated using the Dumas method (Sebecic and Balenovic, 2001) using a Flash EA 1112 Nitrogen and Protein Analyzer (Thermo Scientific) according to Approved method 46-30 (AACC, 1995). Moisture content was measured according to Approved Method 44-15A (AACC, 1995).

\subsection{Gluten protein content in flour}

Gluten proteins were extracted according to Van den Broeck et al. (2009a) from $50 \mathrm{mg}$ wheat flour by addition of $0.5 \mathrm{ml}$ of $50 \%(\mathrm{v} / \mathrm{v})$ aqueous iso-propanol with continuous mixing (MS1 Minishaker, IKA Works, Inc.) at $1000 \mathrm{rpm}$ for $30 \mathrm{~min}$ at room temperature, followed by centrifugation at $10,000 \mathrm{rpm}$ for $10 \mathrm{~min}$ at room temperature. The residue was re-extracted twice with $50 \%$ (v/v) aqueous iso-propanol, $50 \mathrm{mM}$ Tris- $\mathrm{HCl}, \mathrm{pH} 7.5$ containing $1 \%$ (w/v) DTT, for $30 \mathrm{~min}$ at $60{ }^{\circ} \mathrm{C}$ with mixing every 5-10 min, followed by centrifugation at $10,000 \mathrm{rpm}$ for $10 \mathrm{~min}$ at room temperature. After addition of each next extraction solution, the residue was resuspended by shaking in a Fastprep ${ }^{\circledR}$ FP220A Instrument for $10 \mathrm{~s}$ at $6.5 \mathrm{~m} / \mathrm{sec}$ followed by sonication for $10 \mathrm{~min}$ in an ultrasonic bath (Branson 3510, Branson Ultrasonics Corporation). The three obtained supernatants were combined and considered the gluten protein extract. The gluten protein content was quantified using the Biorad Protein Assay (Bio-Rad Laboratories), based on the Bradford dye-binding procedure, according to manufacturer's instruction with BSA as a standard. 


\subsection{SDS-PAGE and immunoblotting}

Wheat gluten proteins and oat avenins were separated on SDSPAGE gels of $10 \%$ and $11 \%$, respectively, as described (Laemmli, 1970) using a Hoefer SE 260 mighty small II system (GE Healthcare) followed by staining with PageBlue ${ }^{\mathrm{TM}}$ (Fermentas).

For immunoblotting, proteins were blotted onto nitrocellulose ( $0.2 \mu \mathrm{m}$, Bio-Rad Laboratories), omitting methanol from the blotting buffer, using a Mini Trans-Blot Cell (Bio-Rad Laboratories) at $100 \mathrm{~V}$ for $1 \mathrm{~h}$. Blots were stained using a MemCode ${ }^{\mathrm{TM}}$ Reversible Protein Stain Kit for Nitrocellulose Membranes (Fisher Scientific) prior to incubation with mAbs. Incubation with mAbs specific for T-cell stimulatory epitopes Glia- $\alpha 9$, Glia- $\alpha 20$, and Glt-156 (LMW-glutenin) (Mitea et al., 2008; Spaenij-Dekking et al., 2005) was performed as described by Cordewener et al. (1995). Antibody binding to the blots was visualized by staining for alkaline phosphatase conjugated secondary antibody, using Nitro Blue tetrazolium (NBT) and 5-Bromo-4-chloro-3-indolyl phosphate (BCIP) (Sigma). Blots were scanned using a Bio-Rad GS-710 Calibrated Imaging Densitometer (Bio-Rad Laboratories) and saved as TIFF images.

\subsection{Two-dimensional gel electrophoresis}

For 2-dimensional gel electrophoresis (2-DE), gluten proteins were separated in the first dimension by isoelectric focusing (IEF). Immobiline Drystrips pH 3-10 of $7 \mathrm{~cm}$ (GE Healthcare) were rehydrated overnight with $10 \mu \mathrm{g}$ protein in rehydration buffer $(6 \mathrm{M}$ urea, $2 \mathrm{M}$ thio-urea, 2\% CHAPS, $20 \mathrm{mM}$ DTT) complemented with $0.5 \%$ IPG buffer $\mathrm{pH} 3-10$ (GE Healthcare) to reach a final volume of $125 \mu \mathrm{l}$ according to manufacturer's instructions. The rehydrated strips were focused on an IPGphor (GE Healthcare) using the following conditions: $300 \mathrm{~V}$ during $30 \mathrm{~min}$, gradient to $1000 \mathrm{~V}$ in $30 \mathrm{~min}$, gradient to $5000 \mathrm{~V}$ in $1 \mathrm{~h} 20 \mathrm{~min}$, step and hold at $5000 \mathrm{~V}$ until $6500 \mathrm{Vh}$. Prior to second dimension, strips were equilibrated for $15 \mathrm{~min}$ in equilibration buffer (6 M urea, 30\% glycerol, 2\% SDS, $50 \mathrm{mM}$ Tris-HCl, pH 8.8) containing $1 \% \mathrm{w} / \mathrm{v}$ DTT, followed by $15 \mathrm{~min}$ in $5 \mathrm{ml}$ equilibration buffer containing $2.5 \% \mathrm{w} / \mathrm{v}$ iodoacetamide. Separation in the second dimension was performed using SDSPAGE gels (10\% for wheat gluten proteins and 11\% for oat avenins) and the SE 260 mighty small II system (GE Healthcare). Gels were stained with PageBlue ${ }^{\mathrm{TM}}$ (Fermentas).

\subsection{Mixing}

Mixing studies were performed with a $2 \mathrm{~g}$ Mixograph (Pin mixer, TMCO, Lincoln, NE, USA) using water absorptions estimated by Approved Method 54-40A (AACC, 1995) using the calculated protein and moisture contents. The quantities of flour and water were chosen to provide a constant $3.5 \mathrm{~g}$ of dough. To all flours, $2 \%$ $\mathrm{NaCl}$ was added. Mixing was performed for $10 \mathrm{~min}$ at $20^{\circ} \mathrm{C}$ in duplicate. Single mixing experiments with flour from deletion line $6 \mathrm{DS}-2$ were in addition performed by replacing the flour with $10 \%$ or $25 \%$ of oat flour. Mixograms were evaluated using Mixsmart ${ }^{\circledR}$ software. Computer-analyzed mixograph parameters obtained included midline peak time (MPT), midline peak height, midline peak width (MPW), midline right slope (MRS), band width at $8 \mathrm{~min}$ (MTxW), and energy to peak (ETP).

\subsection{Extension testing}

Dough for extension testing was mixed to peak in a $10 \mathrm{~g}$ mixograph (National Manufacturing, USA). A dough piece of $2.3 \mathrm{~g}$ was used for stress relaxation measurement, and the rest of the dough was pressed into a Teflon mold pre-warmed to $30^{\circ} \mathrm{C}$ and rested for $45 \mathrm{~min}$ at $30^{\circ} \mathrm{C}$ in a water-saturated atmosphere prior to testing.
Dough strips, four to seven, were removed from the Teflon block, mounted on the Kieffer dough and gluten extensibility rig, and immediately tested on a TA.XT2i texture analyzer (Stable Micro Systems, UK) at a hook speed of $3.3 \mathrm{~mm} / \mathrm{s}$ and a trigger force of $2 \mathrm{~g}$. From the extension graph, the maximum resistance $\left(R_{\max }\right.$ in $\left.\mathrm{g}\right)$ and extensibility (Ext in $\mathrm{mm}$ ) were calculated. $R_{\max }$ is a measure of the stiffness of the dough; a higher $R_{\max }$ reflects a stronger, more stiff dough. Ext is a measure of the elasticity of the dough and a high Ext-value reflects a more viscous and less elastic dough.

\subsection{Stress relaxation}

A dough piece of $2.3 \mathrm{~g}$ obtained from the $10 \mathrm{~g}$ mixograph was placed between two parallel plates (25 mm diameter) of an Advanced Rheometer AR2000 (TA Instruments, USA). The gap between the plates was adjusted to $3 \mathrm{~mm}$ and the dough was covered with paraffin oil to prevent drying out. The dough was rested for $45 \mathrm{~min}$ at $30^{\circ} \mathrm{C}$ to allow relaxation of stresses resulting from dough handling. Then a strain was applied from 0 to $0.2 \mathrm{~s}^{-1}$ in $50 \mathrm{~s}$, after which the dough was allowed to relax for $5 \mathrm{~min}$. The relaxation half time $\left(T_{1 / 2}\right)$ was calculated as the time required for the stress to decay to half the strain. A viscous dough is reflected by a short $T_{1 / 2}$ value, while a high $T_{1 / 2}$ value reflects a more elastic dough.

\subsection{Extraction and addition of oat avenins}

Commercial oat flakes from variety Gigant (De Halm, The Netherlands) were ground in an analytical mill (A 11 Basic, IKAWerke) and $25 \mathrm{~g}$ of the resulting flour was defatted with petroleum ether (60:40) (Weegels et al., 1994) by resuspending three times in $500 \mathrm{ml}$. The flour was collected on filter paper and left to dry overnight in a fume hood. Then, the dry flour $(22.6 \mathrm{~g})$ was extracted once with $120 \mathrm{ml}$ of $50 \%(\mathrm{v} / \mathrm{v}$ ) aqueous iso-propanol by rotation for $30 \mathrm{~min}$ at room temperature, followed by centrifugation at $10,000 \mathrm{rpm}$ for $10 \mathrm{~min}$. The residue was re-extracted once with $50 \mathrm{ml} 50 \%(\mathrm{v} / \mathrm{v}$ ) aqueous iso-propanol. DTT appeared not necessary as a reductant for total avenin extraction. The supernatants were combined and dialyzed against $0.1 \mathrm{mM}$ acetic acid which results in a pH close to that of dough ( $\sim$ pH 6$)$ (Skerritt et al., 1996). After dialysis, the avenin fraction was freeze-dried. Of this freeze-dried oat avenin fraction, $1,2,5,10$, or $20 \mathrm{mg}$ was added to flour of deletion lines 1 AS-3, 1DS-5, 6AS-1, 6DS-2, and 1BS-19/6DS-4. Twogram mixing experiments were performed and parameters obtained included midline peak time (MPT), midline right slope (MRS), band width at $8 \mathrm{~min}$ (MTxW), and energy to peak (ETP).

\subsection{Isolation of glutenin macro polymer (GMP)}

GMP was isolated by suspending $0.5 \mathrm{~g}$ flour in $11 \mathrm{ml} 1.5 \%(\mathrm{w} / \mathrm{v})$ SDS. After ultracentrifugation (Beckmann L-80, 80,000 $\times$ g, $30 \mathrm{~min}$, $20{ }^{\circ} \mathrm{C}$ ) (Graveland et al., 1982) the supernatant was discarded and the thickness of the gel layer was measured. From this, the GMPvolume was calculated in $\mu \mathrm{l} / \mathrm{mg}$ protein. Measurements were performed in duplicate.

\section{Results}

The reduction of CD-stimulating epitopes (Glia- $\alpha 9$ and Glia- $\alpha 20$ ) in the context of quality aspects of wheat dough (regarding mixing, stress relaxation, and extensibility) was analyzed in a selection of deletion lines of T. aestivum cv. Chinese Spring having deletions from the short arms of chromosomes 1 and 6 . Additionally, the capacity of oat avenins to compensate for the deleted gliadins was investigated. 


\subsection{Flour properties}

Flour milling yield of CS wt and the deletion lines was calculated as percentage of flour obtained from the initial total kernel weight. Flour yields obtained after milling and sieving were remarkably lower for the deletion lines 6DS-2 and 1BS-19/6DS-4 compared to CS wt (Table 1), which might be caused by the smaller kernel size. Deletion line 6DS-2 produced a wide variety of seed dimensions, generally smaller that the CS wt seeds. Seeds of deletion line 1BS-19/6DS-4 were comparable to CS wt seeds. Seeds of both deletion lines had a somewhat darker appearance than the CS wt seeds.

Flour water content of CS wt and deletion lines was $12 \%$. Total protein content in flour was $\sim 18 \%$ for CS wt and for deletion lines $1 \mathrm{AS}-3,1 \mathrm{DS}-5$, and $6 \mathrm{AS}-1$, but was lower for deletion line 6DS-2 and higher for deletion lines 6AS-1 and 1BS-19/6DS-4 (Table 1).

The gluten protein content as percentage of the total protein content in the flour (and as percentage of flour) was for CS wt 33\% (5.8\%), for $1 \mathrm{AS}-333 \%$ (6.1\%), for 1DS-5 29\% (5.2\%), for 6 AS-1 $26 \%$ (5.0\%), for 6DS-2 28\% (4.2\%), and for 1BS-19/6DS-4 29\% (5.8\%).

\subsection{SDS-PAGE, immunoblotting and 2-DE}

Gluten protein extracts from flour of CS wt and deletion lines were analyzed by SDS-PAGE and PageBlue staining, immunoblotting and 2-DE. Results are shown in Fig. 1, arrow heads indicate the major differences compared to CS wt. Differences to CS wt in gluten proteins were mostly observed in the B-, C-type LMW-GS and $\alpha / \beta-, \gamma$-gliadin region. Our results showed that all $\omega$-gliadins present in CS wt are still present in deletion line 1AS-3. The deletion in line $1 \mathrm{AS}-3$ is too small to delete $\omega$-gliadins as was shown by MasoudiNejad et al. (2002) who detected the presence of these proteins by A-PAGE. Deletion lines 1DS-5 and 1BS-19/6DS-4 were missing a large number of gluten proteins as was shown by SDS-PAGE and by immunoblotting using mAbs against T-cell epitopes Glia- $\alpha 9$ and Glia- $\alpha 20$. A comparison of immunoblotting (Fig. 1C and D) with total gluten protein staining (Fig. 1B) showed that gluten proteins are present in the deletion lines that did not contain the T-cell stimulatory epitopes Glia- $\alpha 9$ and Glia- $\alpha 20$. Line 1DS-5 was missing several gluten protein bands in the $\omega$-gliadin/D-type LMW-GS region and in the B-, C- type LMW-GS and $\alpha / \beta-, \gamma$-gliadin region. The double deletion line, 1BS-19/6DS-4, was missing the most gluten protein bands because of two deletions in different gluten-encoding loci. The $\omega$-gliadin locus that is removed from this double deletion line is located on chromosome $1 \mathrm{~B}$, and it encodes $\omega$-gliadins with higher molecular masses (estimated by SDS-PAGE) than the $\omega$-gliadins encoded by the locus on the short arm of chromosome 1D that is deleted in line $1 \mathrm{DS}-5$. The $\omega$-gliadins from chromosome $1 \mathrm{D}$ react to both mAbs Glia- $\alpha 9$ and Glia- $\alpha 20$.
To characterize the protein extracts in more detail, 2-DE analysis was performed. These 2-DE gels enabled identification of the absent gluten proteins in the deletion lines more clearly than by SDS-PAGE. Single protein bands on the SDS-PAGE gel (Fig. 1B) were separated into individual protein spots (Fig. 1E). The gluten protein bands from the SDS-PAGE gel that were absent in deletion lines 6DS-2 and 1BS$19 / 6 \mathrm{DS}-4$ appeared to be composed of multiple $\alpha$-gliadins that appeared as separate spots on the 2-DE gel. The protein bands for $\omega$ gliadins were less complex and corresponded to single spots on the 2-DE gel, as is shown by a comparison with the lines having deletions from chromosome 1 (1DS-5 and 1BS-19/6DS-4). Spots on the 2-DE gels corresponded to single proteins, or to a few nearly identical proteins.

\subsection{Mixing}

Dough mixing behavior and technological dough properties reflect the composition and structure of the gluten protein profile in the dough. A high glutenin/gliadin (glu/gli) ratio results in a more stiff and less extensible dough, whereas a high HMW-/LMW-GS ratio will increase dough elasticity (for a review see Hamer et al., 2009). In addition, other compensation type of factors also influences dough mixing behavior and properties. For example, if one type of gliadin is deleted, it is possible that the synthesis of another type of gliadin is increased, effectively keeping the glutenin/gliadin ratio constant. In addition, deleting one type of LMW-GS could lead to an increased synthesis of either gliadins or glutenins, leading to an overall change in glu/gli ratio.

Mixograms obtained from the $2 \mathrm{~g}$ mixograph were evaluated using Mixsmart ${ }^{\circledR}$ software. Optimum water addition for mixing was based on flour protein content and flour water content according to Approved Method 54-40A (AACC, 1995). This procedure provided good curves for all flours tested. Parameters selected for further analysis included midline peak time (MPT), midline peak height, midline peak width (MPW), midline right slope (MRS), band width at $8 \mathrm{~min}$ (MTxW), and energy to peak (ETP). The results are shown in Table 1 . The CS wt dough was weak, with a very short mixing time (MPT) and required energy input compared to high quality wheat used for bread making. Deletion of gliadins (as in lines 6DS-2 and 1BS-19/6DS-4) resulted in higher levels of required energy to peak (ETP) and larger values of MtxW, indicating a relatively higher content of glutenins (Don et al., 2006). Alternatively, deleting LMW-GS (as with line 1DS-5) resulted in a lower MtxW and a lower ETP, indicating a relatively higher content of gliadins. These data are reflected by changes in GMP content (see Section 3.7). Parameters were correlated individually and relatively high correlations were shown for all mixograph parameters except for correlation between values for MPH and MRS $\left(R^{2}=-0.32\right)$. Values for FPC showed high

Table 1

Dough parameters obtained for 'Chinese Spring' wild type and deletion lines.

\begin{tabular}{|c|c|c|c|c|c|c|}
\hline parameter & CS wt & $1 \mathrm{AS}-3$ & $1 \mathrm{DS}-5$ & $6 \mathrm{AS}-1$ & $6 D S-2$ & 1BS-19/6DS-4 \\
\hline FY & 47 & 44 & 45 & 41 & 34 & 34 \\
\hline FPC & $17.6 \pm 0.3$ & $18.1 \pm 0.4$ & $17.7 \pm 0.3$ & $19.0 \pm 0.8$ & $15.2 \pm 1.2$ & $20.3 \pm 0.3$ \\
\hline MPT & $1.8 \pm 0.2$ & $1.6 \pm 0.2$ & $1.5 \pm 0.0$ & $2.0 \pm 0.0$ & $2.3 \pm 0.1$ & $2.2 \pm 0.1$ \\
\hline $\mathrm{MPH}$ & $65.3 \pm 0.2$ & $72.0 \pm 0.5$ & $65.5 \pm 0.4$ & $67.5 \pm 1.7$ & $63.4 \pm 3.0$ & $83.2 \pm 0.3$ \\
\hline MPW & $32.3 \pm 1.2$ & $30.0 \pm 3.1$ & $29.4 \pm 0.6$ & $34.1 \pm 1.2$ & $34.3 \pm 2.6$ & $38.9 \pm 0.8$ \\
\hline MRS & $-7.2 \pm 0.9$ & $-10.0 \pm 0.7$ & $-9.9 \pm 0.0$ & $-4.2 \pm 0.9$ & $-4.0 \pm 1.3$ & $-7.9 \pm 1.1$ \\
\hline MTxW & $15.4 \pm 0.4$ & $16.0 \pm 0.1$ & $13.7 \pm 0.1$ & $16.8 \pm 0.4$ & $19.0 \pm 1.3$ & $18.7 \pm 0.3$ \\
\hline ETP & $83.5 \pm 11.7$ & $89.3 \pm 13.4$ & $70.4 \pm 3.2$ & $89.8 \pm 3.5$ & $97.1 \pm 10.8$ & $123.4 \pm 6.4$ \\
\hline$R_{\max }$ & $5.9 \pm 0.9$ & $4.8 \pm 0.6$ & $3.9 \pm 0.4$ & $7.2 \pm 0.7$ & $9.8 \pm 0.9$ & $11.9 \pm 0.8$ \\
\hline Ext & $115.7 \pm 10.3$ & $130.4 \pm 27.4$ & $136.2 \pm 31.2$ & $129.9 \pm 14.1$ & $102.3 \pm 17.1$ & $101.7 \pm 14.5$ \\
\hline $\mathrm{T}_{1 / 2}$ & 21.3 & 20.5 & 19.3 & 22.3 & 24.1 & 23.1 \\
\hline GMP & $15.3 \pm 0.0$ & $14.8 \pm 0.2$ & $13.6 \pm 1.9$ & $18.7 \pm 0.7$ & $17.3 \pm 1.2$ & $17.5 \pm 1.6$ \\
\hline
\end{tabular}

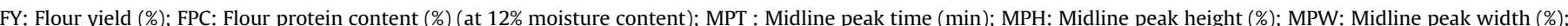

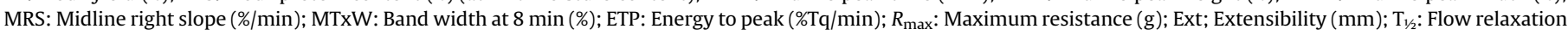
half time (sec); GMP: GMP-volume ( $\mu \mathrm{l} / \mathrm{mg}$ protein). 
correlation with MPH $\left(R^{2}=0.77\right)$ and reasonable correlation with $\operatorname{MPW}\left(R^{2}=0.41\right)$.

\subsection{Extension testing}

Dough extension relates to its gas-holding properties during bread making (Mann et al., 2005). Relevant extension parameters are extensibility (Ext in $\mathrm{mm}$ ) and maximum resistance $\left(R_{\max }\right.$ in $\mathrm{g}$ ) (Table 1 ). Values for $R_{\max }$ were higher for deletion lines 6DS-2 and 1BS-19/6DS-4 and values for Ext were lower compared to CS wt, assuming a more stiff and less extensible dough. For deletion lines 1AS-3 and 1DS-5, values for the two parameters were lower compared to CS wt, indicating a weaker dough. High correlations were found between values for $R_{\max }$ and values for the other dough parameters. The correlation between $R_{\max }$ and Ext was high $\left(R^{2}=-0.885\right)$ and inversed. Most correlations between Ext and the other dough parameters were generally high but inversed.

\subsection{Stress relaxation}

In stress relaxation experiments, a mechanical strain is applied to the dough to induce a stress. The time needed for relaxation of this stress after removing the strain provides information on the structure of the dough (Weegels et al., 1995). A fast relaxation may indicate the presence of small structures, whereas a slow relaxation may indicate the presence of larger structures. A piece of the same dough material as used for extension testing was used for stress relaxation testing. The relaxation half time $\left(T_{1 / 2}\right.$ in $\left.\mathrm{sec}\right)$ was calculated for the stress to decay to half the strain. Although the data were obtained from a single experiment because of limited flour starting material, a clear trend became visible. For deletion lines 6DS-2 and 1BS-19/ 6DS- 4 the $\mathrm{T}_{1 / 2}$ was increased by $2.8 \mathrm{~s}$ and $1.8 \mathrm{~s}$, respectively, compared to CS wt $\left(\mathrm{T}_{1 / 2}=21.3 \mathrm{~s}\right)$, which is an increase of $13.4 \%$ and $8.5 \%$, respectively. An increased relaxation half time indicates a stronger gluten network. For deletion lines 1AS-3 and 1DS-5 the $T_{1 / 2}$ was decreased by $0.8 \mathrm{~s}$ and $1.0 \mathrm{~s}$, respectively, compared to CS wt, which is a decrease of $3.8 \%$ and $4.7 \%$ respectively. Relaxation data correlated highly with the other obtained mixing parameters.

When deletions lead to a higher glu/gli ratio (as was the case in lines 6DS-2 and 1BS-19/6DS-4), the stiffness of the dough is increased, the extensibility is decreased, and the flow relaxation half time $\left(T_{1 / 2}\right)$ is increased. When deletions lead to a lower glu/gli ratio (as with lines 1AS-3 and 1DS-5), the reverse was observed. These observations are completely in line with current theory (Hamer et al., 2009).

\subsection{Flour and avenins from oat and addition to wheat flour}

In order to investigate the potential of oat avenins to replace the absent gliadins and to restore dough quality, oat flour was added to flour of the wheat deletion line 6DS- 2 because the $\alpha$-gliadinencoding locus is deleted in this line. Total protein content in oat flour was $10.8 \% \pm 0.1$ and water content in oat flour was $10 \%$. The avenin content in the oat flour was $7.7 \mathrm{mg} / \mathrm{g}(0.8 \%)$. Oat flour is not suitable for dough preparation because oat gluten proteins do not possess the unique viscoelastic properties as wheat gluten proteins, especially by the lack of glutenins (Fig. 2 and Table 2). Oat flour was added to flour of deletion line 6DS- 2 and tested by using the $2 \mathrm{~g}$ mixograph to see whether this would affect dough mixing properties. Replacing $10 \%$ of the 6DS-2 flour with oat flour did not significantly affect the dough mixing properties. However, replacing $25 \%$ of the 6DS-2 flour with oat flour resulted in a dough with decreased values for MPH, MPW, and MTxW and less mixing tolerance.
Because substitution with oat flour also added other components, which may influence baking quality and taste, we decided to use the avenin fraction from oat. This avenin preparation contained several protein bands consisting of single avenins (Fig. 3A and B). Six protein bands were isolated from SDS-PAGE gel and identified by LC-MS/MS. The peptide sequences obtained could be identified as oat avenin sequences according to the Mascot protein database (results see Supplementary Table). The avenins were analyzed by immunoblotting for the presence of T-cell stimulatory epitopes known from wheat. No staining was observed using mAbs against epitopes Glia- $\alpha 9$, Glia- $\alpha 20$, and Glt-156 (LMW-1 and LMW-2) (Mitea et al., 2008; Spaenij-Dekking et al., 2005) when analyzing $10 \mu \mathrm{g}$ of avenins, as was expected (results not shown). Of the lyophilized oat avenin fraction, 1, 2, 5, 10, or $20 \mathrm{mg}$ was added to flour of deletion lines 1AS-3, 1DS-5, 6AS-1, 6DS-2, and 1BS-19/6DS4. Two gram mixing experiments were performed and parameters measured included midline peak time (MPT), midline right slope (MRS), band width at $8 \mathrm{~min}$ (MTxW), and energy to peak (ETP). Addition of $5 \mathrm{mg}$ of avenins to CS wt flour resulted in a decreased MPT and ETP, whereas MRS was highly increased. Addition of 2 or $5 \mathrm{mg}$ avenins to flour of deletion lines 1AS-3 and 1DS-5 resulted in decreased MPT, MRS, and ETP. The MTxW did not significantly change for addition of $5 \mathrm{mg}$ to CS wt and both deletion lines 1AS-3 and 1DS-5. Addition of 2 or $5 \mathrm{mg}$ avenins to flour of deletion line 6AS- 1 only increased MRS. Addition of $5 \mathrm{mg}$ to deletion line 1BS-19/ 6DS-4 did not significantly change MPT and ETP, but the MRS was highly decreased. Addition of $20 \mathrm{mg}$ resulted in a decrease in MPT and MRS. Results for addition of avenins to flour of deletion line 6DS-2 are shown in Table 3. The data show that dough strength of deletion line 6DS-2 increased up to addition of $5 \mathrm{mg}$ avenins. Addition of $20 \mathrm{mg}$ avenins, however, resulted in a weaker dough. Addition of 1, 2, 5, and $20 \mathrm{mg}$ of avenins to flour of deletion line 6DS-2 corresponded to addition of $0.3 \%, 0.7 \%, 1.6 \%$, and $6.6 \%$ protein, respectively.

\subsection{GMP content}

Glutenin macro polymer was isolated from CS wt, 1AS-3, 1DS-5, 6AS-1, 6DS-2, 1BS-19/6DS-4, CS wt plus $1 \%$ oat avenins, and 6DS-2 plus $1 \%$ oat avenins. GMP was isolated from wheat flour by suspension in $1.5 \%(\mathrm{w} / \mathrm{v})$ SDS.

GMP isolated from CS wt and deletion lines showed different textural characteristics. GMP isolated from CS wt and deletion lines 1AS-3 and 1DS-5 appeared to be watery and flowed easily from the tube after removing the supernatant after ultracentrifugation. The GMP content from deletion lines 6DS-2 and 1BS-19/6DS-4 was higher and the GMP gel was clearly more stiff and did not flow at all. The GMP isolated from the flours with added oat avenins did not appear different compared with the GMP from the flours without addition of oat avenins.

\subsection{Deletion line 6AS-1}

Deletion line 6AS-1 turned out to be heterozygous as was indicated by the WGGRC and was confirmed by results from SDSPAGE and immunoblotting (Fig. 1B-D). Data obtained from mixing and extension testing did not reveal significant differences compared with CS wt, but this may be due to the fact that possible effects of the deletion are masked by the presence of protein produced in heterozygous seeds or in wt seeds. Indeed, data from stress relaxation testing $\left(\mathrm{T}_{1 / 2}\right)$ and GMP extraction did show differences compared to CS wt. These values were increased indicating an increased dough strength. 

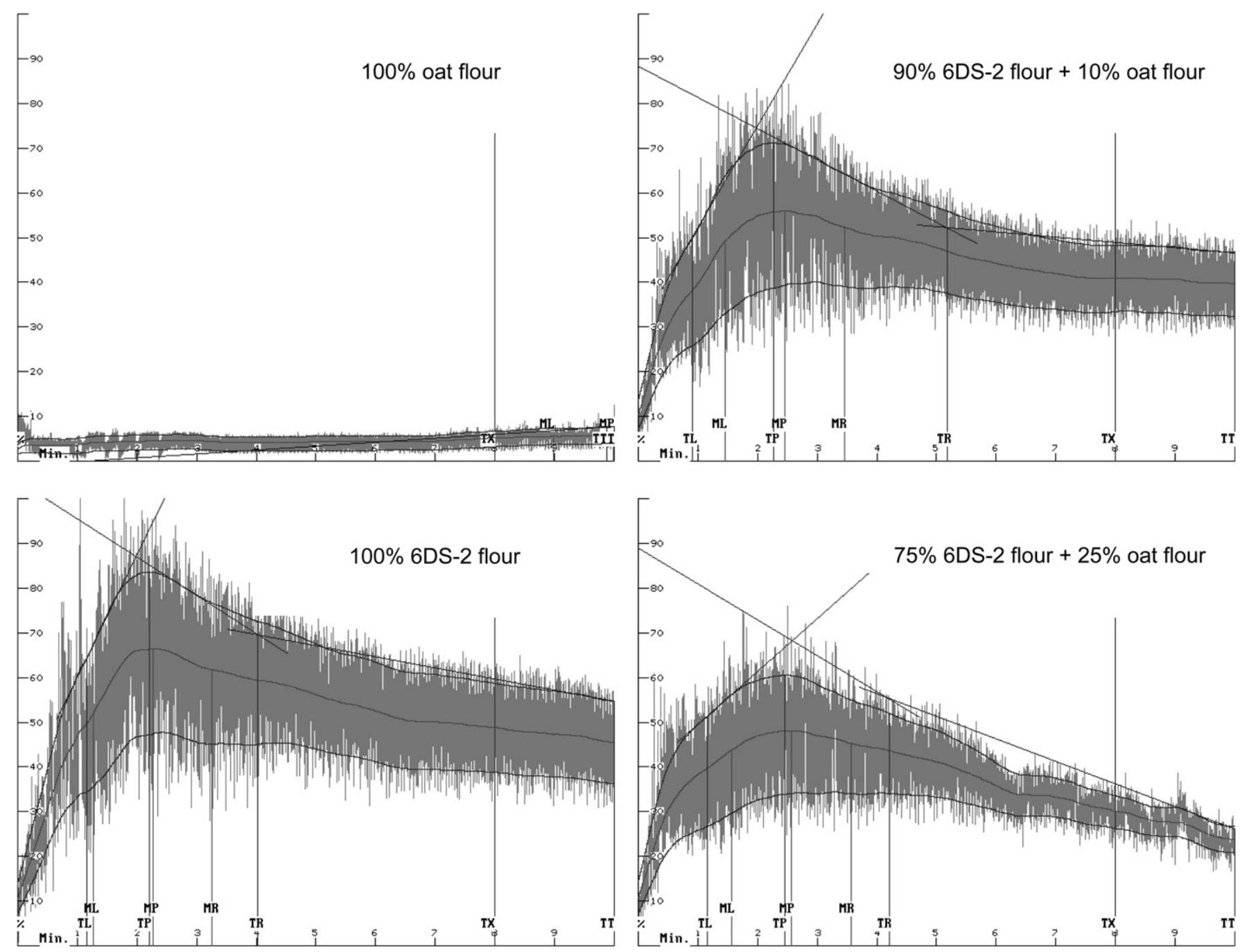

Fig. 2. Mixograms of flour from deletion line 6DS-2, oat flour, and blends.

\section{Discussion}

In this study, various deletion lines of bread wheat 'Chinese Spring' were analyzed for the effect that elimination of specific groups of gluten proteins (that contain specific CD-stimulating epitopes) might have on dough-making quality. The selected lines have deletions of gluten-encoding loci present on the short arms of chromosomes 1 and 6.

Storage proteins account for about $50 \%$ of the total protein in mature cereal grains (Shewry and Halford, 2002) of which $80 \%$ comprises gluten proteins. This means that about $40 \%$ of the total protein in wheat consists of gluten protein. Gluten protein content obtained from CS wt and deletion lines was not as high as expected.

Table 2

Addition of oat flour to deletion line 6DS-2. Comparison of values obtained for $2 \mathrm{~g}$ mixograph parameters.

\begin{tabular}{lllllrr}
\hline & MPT & MPH & MPW & MRS & MTxW & ETP \\
\hline Oat & - & - & - & - & 3.5 & - \\
6DS-2 & 2.3 & 63.4 & 34.3 & -4.0 & 19.0 & 97.1 \\
6DS-2:oat 9:1 & 2.5 & 55.9 & 31.5 & -4.3 & 14.9 & 102.0 \\
6DS-2:oat 3:1 & 2.6 & 48.1 & 26.3 & -3.6 & 7.3 & 98.0 \\
\hline
\end{tabular}

MPT: Midline peak time (min); MPH: Midline peak height (\%); MPW: Midline peak width (\%); MRS: Midline right slope (\%/min); MTxW: Band width at $8 \mathrm{~min}(\%)$; ETP: Energy to peak (\%Tq/min).
It was $\sim 30 \%$ from the total protein content instead of the expected $40 \%$. This may be explained by the fact that most gluten proteins are located in the sub-aleuronic layer (Tosi et al., 2009; Van Herpen et al., 2008), which partially remains attached to the bran after one round of milling and sieving.

Kernel texture is known to influence milling yield (Campbell et al., 2007). It could be that seed development and, as a result, milling yield are influenced by the 6DS deletion. Although from the literature, the trait for milling yield is not mapped on chromosome $6 \mathrm{D}$, it seems to be related with e.g. the Pinb locus on the short arm of chromosome 5A, B, and D (Campbell et al., 2001; Campbell et al., 2007; Mansur et al., 1990; Smith et al., 2001). Deletion line 6DS-2 also has a 5BS deletion, whereas deletion line 1BS-19/6DS-4 does not. In addition, a minor locus for kernel hardness is mapped to chromosome 6D (Perretant et al., 2000; Sourdille et al., 1996).

The overall gluten protein content is not changed in the analyzed deletion lines. This means that if gluten- encoding loci are deleted, the amount of protein synthesized from the remaining gluten loci must have increased. It can be expected that removal of glutenencoding loci will affect dough properties because of a change in the glu/gli ratio and in the HMW-/LMW-GS ratio. 'Chinese Spring' has null, $7+8$, and $2+12$ HMW-GS at the Glu-1 loci, which results in poor baking quality (Garg et al., 2009; Shewry et al., 1994, 1997) and in a sticky and weak dough (Payne et al., 1985). The presence of gliadins can 'dilute' the gluten network and can make the dough less 


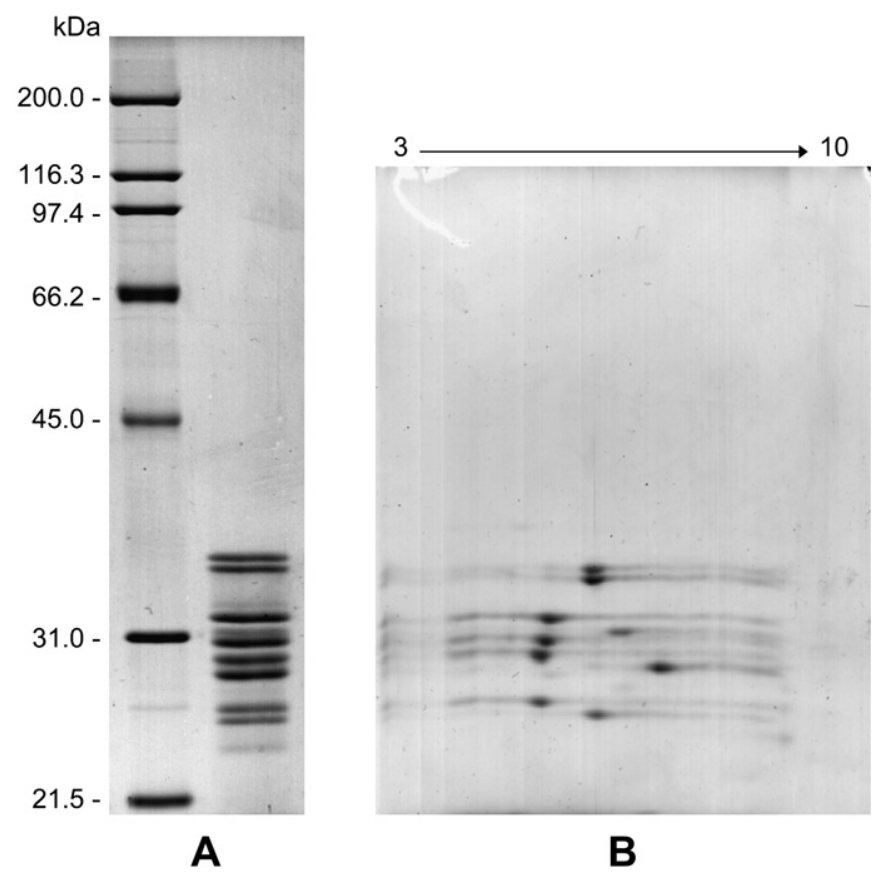

Fig. 3. Avenins extracted from oat flakes ('Gigant') separated by (A) SDS-PAGE (11\%) and (B) 2-DE, stained by PageBlue.

stiff and more extensible (Chakraborty and Khan, 1988; Payne et al., 1979; Song and Zheng, 2008; Weegels et al., 1994). Addition of gliadins, especially $\omega$ - and $\alpha$-gliadins, was shown to weaken the dough by decreasing the glu/gli ratio, resulting in decreased mixing time and increased extensibility (Fido et al., 1997; Uthayakumaran et al., 1999, 2001). Therefore, it was assumed that removing gliadin-encoding loci, as in deletion lines 6DS-2 and 1BS-19/6DS-4, would result in a less elastic and more stiff dough when compared to CS wt, because of higher amounts of glutenins and an increase in glu/ gli ratio. The latter is generally associated with a decrease in extensibility (Uthayakumaran et al., 1999) and is known to increase mixing time (MacRitchie, 1985). Dough extensibility and resistance to extension can be related to gas-holding capacity of dough during bread making (Mann et al., 2005). The ability of dough to retain gas is of key importance. Gianibelli et al. (1998) (from MacRitchie and Lafiandra, 2001) have shown that glu/gli ratios could be increased by deletion of gliadins encoded by the Gli-2 loci, which increased MPT and polymeric protein. Deletion lines 1AS-3 and 1DS-5 indeed resulted in weaker doughs. The few proteins, most likely some LMW-GS that were removed from deletion line 1AS-3 apparently have sufficient impact to make the formation of a nice gluten network more difficult. The decrease in dough quality in deletion line $1 \mathrm{DS}-5$ may be caused by the removal of the linked $\omega$-gliadins or

\section{Table 3}

Addition of purified oat avenins to flour of deletion line 6DS-2. Comparison of values obtained for 2 g-mixograph parameters.

\begin{tabular}{llllllll}
\hline & MPT & MPH & MPW & MRS & MTxW & ETP & GMP \\
\hline 4086 & 1.8 & 68.1 & 32.2 & -9.5 & 15.4 & 85.3 & $15.3 \pm 0.0$ \\
$4086+2 \mathrm{mg}$ avenins & - & - & - & - & - & - & $15.9 \pm 1.1$ \\
$4086+5 \mathrm{mg}$ avenins & 1.4 & 63.9 & 31.8 & 0.7 & 14.8 & 65.7 & - \\
$6 \mathrm{DS}-2$ & 2.1 & 70.7 & 34.2 & -5.8 & 17.3 & 106.0 & $17.3 \pm 1.2$ \\
$6 \mathrm{DS}-2+1 \mathrm{mg}$ avenins & 2.3 & 65.7 & 35.4 & -4.9 & 19.1 & 105.2 & - \\
6DS-2 + $2 \mathrm{mg}$ avenins & 2.6 & 67.1 & 36.3 & -3.0 & 19.0 & 122.0 & $16.6 \pm 0.0$ \\
6DS-2 $+5 \mathrm{mg}$ avenins & 2.5 & 67.4 & 36.4 & -1.0 & 18.4 & 123.4 & - \\
6DS-2 + 20 mg avenins & 1.8 & 67.9 & 29.7 & -10.0 & 16.1 & 78.9 & - \\
\hline
\end{tabular}

MPT: Midline peak time (min); MPH: Midline peak height (\%); MPW: Midline peak width (\%); MRS: Midline right slope (\%/min); MTxW: Band width at $8 \mathrm{~min}(\%)$; ETP: Energy to peak (\%Tq/min); GMP: GMP-volume ( $\mu \mathrm{l} / \mathrm{mg})$. by removal of LMW-GS, which will decrease the glu/gli ratio and the formation of a good gluten network. The two linked 1D $\omega$-gliadins are referred to as D-type LMW-GS (Masci et al., 1993, 1999) and contain a small number of cysteine residues by which they can interact with the polymeric gluten fraction. There is an increasing interest in $\omega$-gliadins and D-type LMW-GS because of their relevance to baking quality (DuPont et al., 2000; Wang et al., 2008) and our results indicate that they may contain T-cell stimulatory $\alpha$ gliadin epitopes. Several authors have shown that $\omega$-gliadins may contain epitopes involved in gluten-sensitive response of CDpatients (Camarca et al., 2009; Denery-Papini et al., 1999; Ensari et al., 1998).

In this study, oat flour and oat avenins were added separately to flour of deletion line 6DS-2 to analyze the effect on dough properties, and to determine whether the effect of the deletion could be reversed by addition of the gliadin-like proteins from oat. Oats have been proven to be well tolerated in CD-patients as part of a glutenfree diet (Pulido et al., 2009 and references therein) and to contribute to the improvement of the nutritional value of a glutenfree diet (Butt et al., 2008). By addition of oat flour, not only avenins are added but also lipids and $\beta$-glucans, which will have a negative effect on the dough properties (Zhang et al., 1998). High $\beta$-glucan content was shown to increase water absorption and also to decrease dough plasticity (Mariotti et al., 2006; Oomah, 1983). Therefore, only limited amounts of oat flour can be included in wheat flour. Flander et al. (2007) reported that a reasonable quality bread could be prepared with addition of $51 \mathrm{~g}$ oat flour per $100 \mathrm{~g}$ of wheat flour. This may be explained by the assumption that the monomeric oat avenins alter the ratio between monomeric and polymeric proteins in wheat.

Addition of purified oat avenins to the wheat flour might circumvent introduction of the negative effects by addition of oat flour. Our results showed that, to a certain level, the addition of oat avenins improves dough quality and probably strengthens the formation of the gluten network. Addition of oat avenins may be different from incorporation, in which firstly the disulfide linkages are reduced before addition (Békés et al., 1994). When gluten proteins are added, no specific treatment is applied to the gluten proteins or the dough. When gluten proteins are 'incorporated', the formed glutenin network in the dough is reduced by addition of a reducing reagent, DTT, followed by addition of the newly to add gluten proteins and this mixture is then oxidized by addition of an oxidizing reagent, e.g. $\mathrm{KIO}_{3}$. However, others have found that there is a similarity between the effects of 'addition' and 'incorporation' of glutenin subunits on dough properties (Verbruggen et al., 2001). Especially in deletion line 6DS-2, we observed an improvement of the dough, which may be because the avenins integrate in the wheat gluten network, although it is unknown whether avenins posses free SH-groups. Hydrogen bonding, hydrophobic interactions, or ionic bonding between avenins and the gluten network may also cause a stronger gluten network. The increase in values for mixing parameters suggests an increase of the HMW-/LMW-GS ratio (Uthayakumaran et al., 2000) or an increased glu/gli ratio (MacRitchie and Lafiandra, 2001). When the amount of added avenins is too high, as was seen when $20 \mathrm{mg}$ avenins were added to two g 6DS-2 flour, the gluten network became diluted again, which resulted in a weaker dough. This result showed that reduction of CD-stimulating epitopes from gluten proteins in wheat to reduce the response in CD-patients influences the dough-making quality and that this could be compensated by addition of purified avenins. Unfortunately, for industrial use, the extraction of avenins from oats would be a costly and labor-intensive process. It has been demonstrated that heterologous expressed gluten reveal the same characteristic protein function as native gluten proteins (Tamás and Shewry, 2006). To simplify the process of purification, avenins 
could be recombinantly expressed in bacteria or yeast, but this would have a high cost price as well. Another option to improve the dough protein network is the addition of additives such as enzymes and hydrocolloids as described by Hüttner and Arendt (2010, and references therein).

Molberg et al. (2005) showed by using deletion lines 1BS-19/ 6DS- 4 and 6DS-2 in human T-cell testing a significant decrease in Tcell response of T-cells from a patient responding to the 33-mer described by Shan et al. (2002, 2005). A large amount of CDpatients, about $50 \%$, respond to the 33 -mer that contains the immunodominant epitopes Glia- $\alpha 2$ and Glia- $\alpha 9$ (Camarca et al., 2009; Vader et al., 2002). Therefore, the removal of the Gli-D2 locus from the short arm of chromosome 6D in wheat may be an important strategy toward the development of CD-safe wheat and food products. To be able to use the deletion of the Gli-D2 locus in commercial wheat varieties, the locus may be deleted from wheat varieties with a high production and intrinsically good industrial properties. Preferably, the Gli-D2 locus needs to be deleted without eliminating larger parts of the chromosomes, as this may affect the fitness of the crop.

\section{Conclusion}

Removing of gluten-encoding loci reduces T-cell stimulatory epitopes causing $\mathrm{CD}$, but also affects dough quality. In 'Chinese Spring', deletion of the Gli-D1/Glu-D3 loci decreased dough quality (i.e. dough strength and elasticity), but deletion of the Gli-D2 locus improved dough strength by a decrease in elasticity. Removal of the Gli-D2 locus from the short arm of chromosome 6D in wheat may be an important strategy toward the development of CD-safe wheat and food products. Oat avenins are a good alternative for wheat gliadins and could be added to the flour of certain wheat lines that lack loci encoding CD-stimulating gluten proteins, to improve or restore dough quality.

\section{Acknowledgments}

The authors would like to thank Jerry van Maanen (TNO Quality of Life, Zeist, The Netherlands) for support with rheological and texture measurements; Cees Heddes (TNO Quality of Life, Zeist, The Netherlands) for support with milling and mixing; Peter de Gijsel (Wageningen University, The Netherlands) for support with the Nitrogen and Protein Analyzer. We thank the WGGRC Kansas State University, USA, for providing us with Chinese Spring deletion lines. Many thanks to Prof. dr. Frits Koning and Dr. Liesbeth Dekking from Leiden University Medical Centre, The Netherlands, for providing us with the mAbs. This research was funded by the Celiac Disease Consortium, an Innovative Cluster approved by the Netherlands Genomics Initiative and partially funded by the Dutch Government (BSIK03009), and by the Dutch Ministry of Agriculture, Nature, and Food Quality of The Netherlands through the DLO program 'Plant and Animal for Human Health' (project KB-05-001-019-PRI).

\section{Appendix. Supplementary material}

The supplementary data associated with this article can be found in the on-line version at doi:10.1016/j.jcs.2010.12.004

\section{References}

AACC, 1995. Approved Methods of the American Association of Cereal Chemists, nineth ed. The Association, St. Paul.

Arentz-Hansen, E.H., Korner, R., Molberg, Ø., Quarsten, H., Vader, W., Kooy, Y.M.C., Lundin, K.E.A., Koning, F., Roepstorff, P., Sollid, L.M., McAdam, S.N., 2000a. The intestinal T-cell response to $\alpha$-gliadin in adult celiac disease is focused on a single deamidated glutamine targeted by tissue transglutaminase. Journal of Experimental Medicine 191, 603-612.

Arentz-Hansen, E.H., McAdam, S.N., Molberg, Ø., Kristiansen, C., Sollid, L.M., 2000b. Production of a panel of recombinant gliadins for the characterisation of T cell reactivity in coeliac disease. Gut 46, 46-51.

Arentz-Hansen, E.H., McAdam, S.N., Molberg, Ø., Fleckenstein, B., Lundin, K.E.A., Jorgensen, T.J.D., Jung, G., Roepstorff, P., Sollid, L.M., 2002. Celiac lesion T cells recognize epitopes that cluster in regions of gliadins rich in proline residues. Gastroenterology 123, 803-809.

Atchison, J., Head, L., Gates, A., 2010. Wheat as food, wheat as industrial substance; comparative geographies of transformation and mobility. Geoforum 41, 236-246.

Békés, F., Gras, P.W., Gupta, R.B., 1994. Mixing properties as a measure of reversible reduction and doxidation of doughs. Cereal Chemistry 71, 44-50.

Branlard, G., Dardevet, M., Saccomano, R., Lagoutte, F., Gourdon, J., 2001. Genetic diversity of wheat storage proteins and bread wheat quality. Euphytica 119, 59-67.

Butt, M., Tahir-Nadeem, M., Khan, M., Shabir, R., Butt, M., 2008. Oat: unique among the cereals. European Journal of Nutrition 47, 68-79.

Camarca, A., Anderson, R.P., Mamone, G., Fierro, O., Facchiano, A., Costantini, S., Zanzi, D., Sidney, J., Auricchio, S., Sette, A., Troncone, R., Gianfrani, C., 2009. Intestinal T cell responses to gluten peptides are largely heterogeneous: implications for a peptide-based therapy in celiac disease. Journal of Immunology 182, $4158-4166$

Campbell, K.G., Finney, P.L., Bergman, C.J., Gualberto, D.G., Anderson, J.A., Giroux, M.J., Siritunga, D., Zhu, J., Gendre, F., Roue, C., Verel, A., Sorrells, M.E., 2001. Quantitative trait loci associated with milling and baking quality in a soft hard wheat cross. Crop Science 41, 1275-1285.

Campbell, J.B., Martin, J.M., Crutcher, F., Meyer, F.D., Clark, D.R., Giroux, M.J., 2007. Effects on soft wheat (Triticum aestivum L.) quality of increased puroindoline dosage1. Cereal Chemistry 84, 80-87.

Chakraborty, K., Khan, K., 1988. Biochemical and breadmaking properties of wheat protein components. II. Reconstitution baking studies of protein fractions from various isolation procedures. Cereal Chemistry 65, 340-544.

Cordewener, J.H.G., Hause, G., Görgen, E., Busink, R., Hause, B., Dons, H.J.M., Van Lammeren, A.A.M., Van Lookeren Campagne, M.M., Pechan, P., 1995. Changes in synthesis and localization of members of the $70-\mathrm{kDa}$ class of heat-shock proteins accompany the induction of embryogenesis in Brassica napus L. microspores. Planta 196, 747-755.

D’Ovidio, R., Masci, S., 2004. The low-molecular-weight glutenin subunits of wheat gluten. Journal of Cereal Science 39, 321-339.

Day, L., Augustin, M.A., Batey, I.L., Wrigley, C.W., 2006. Wheat-gluten uses and industry needs. Trends in Food Science \& Technology 17, 82-90.

Denery-Papini, S., Nicolas, Y., Popineau, Y., 1999. Efficiency and limitations of immunochemical assays for the testing of gluten-free foods. Journal of Cereal Science 30, 121-131.

Don, C., Lichtendonk, W., Plijter, J.J., Hamer, R.J., 2003. Glutenin macropolymer: a gel formed by glutenin particles. Journal of Cereal Science 37, 1-7.

Don, C., Mann, G., Bekes, F., Hamer, R.J., 2006. HMW-GS affect the properties of glutenin particles in GMP and thus flour quality. Journal of Cereal Science 44, 127-136.

DuPont, F.M., Vensel, W.H., Chan, R., Kasarda, D.D., 2000. Characterization of the 1Btype $\omega$-gliadins from Triticum aestivum cultivar Butte. Cereal Chemistry 77, 607-614.

Endo, T.R., Gill, B.S., 1996. The deletion stocks of common wheat. Journal of Heredity 87, 295-307.

Ensari, A., Marsh, M.N., Moriarty, K.J., Moore, C.M., Fido, R.J., Tatham, A.S., 1998. Studies in vivo of $\omega$-gliadins in gluten sensitivity (coeliac sprue disease). Clinical Science 95, 419-424.

Fido, R.J., Békés, F., Gras, P.W., Tatham, A.S., 1997. Effects of $\alpha-, \beta-, \gamma$ - and $\omega$-gliadins on the dough mixing properties of wheat flour. Journal of Cereal Science 26 , 271-277.

Flander, L., Salmenkallio-Marttila, M., Suortti, T., Autio, K., 2007. Optimization of ingredients and baking process for improved wholemeal oat bread quality. LWT - Food Science and Technology 40, 860-870.

Garg, M., Tanaka, H., Tsujimoto, H., 2009. Exploration of Triticeae seed storage proteins for improvement of wheat end-product quality. Breeding Science 59, 519-528.

Gianibelli, M.C., Larroque, O.R., Chan, P., Margiotta, B., De Ambrogio, E. MacRitchie, F., Lafiandra, D., 1998. Effect of allelic variants at the Gli-1/Glu-3 and Gli-2 loci on mixing properties. In: Slinkard, A.E. (Ed.), Proceedings International Wheat Genetics Symposium, nineth ed. University of Saskatchewan, Saskatchewan, SK, Canada, pp. 154-156.

Gill, B.S., Friebe, B., Endo, T.R., 1991. Standard karyotype and nomenclature system for description of chromosome bands and structural aberrations in wheat (Triticum aestivum). Genome 34, 830-839.

Graveland, A., Bosveld, P., Lichtendonk, W.J., Moonen, H.H.E., Scheepstra, A., 1982. Extraction and fractionation of wheat flour proteins. Journal of the Science of Food and Agriculture 33, 1117-1128.

Gupta, R.B., Masci, S., Lafiandra, D., Bariana, H.S., MacRitchie, F., 1996. Accumulation of protein subunits and their polymers in developing grains of hexaploid wheats. Journal of Experimental Botany 47, 1377-1385.

Hamer, R.J., MacRitchie, F., Weegels, P.L., 2009. Structure and functional properties of gluten. In: Khan, K., Shewry, P. (Eds.), Wheat: Chemistry and Technology. Eagan Press, Eagan, USA. 
Harberd, N.P., Bartels, D., Thompson, R.D., 1986. DNA restriction-fragment variation in the gene family encoding high molecular weight (HMW) glutenin subunits of wheat. Biochemical Genetics 24, 579-596.

Hüttner, E.K., Arendt, E.K., 2010. Recent advances in gluten-free baking and the current status of oats. Trends in Food Science \& Technology 21, 303-312.

Janatuinen, E.K., Kemppainen, T.A., Julkunen, R.J.K., Kosma, V.M., Maki, M., Heikkinen, M., Uusitupa, M.I.J., 2002. No harm from five year ingestion of oats in coeliac disease. Gut 50, 332-335.

Laemmli, U.K., 1970. Cleavage of structural proteins during the assembly of the head of bacteriophage T4. Nature 227, 680-685.

Lohi, S., Mustalahti, K., Kaukinen, K., Laurila, K., Collin, P., Rissanen, H., Lohi, O., Bravi, E., Gasparin, M., Reunanen, A., Mäki, M., 2007. Increasing prevalence of coeliac disease over time. Alimentary Pharmacology \& Therapeutics 26, 1217-1225.

MacRitchie, F., 1985. Studies of the methodology for fractionation and reconstitution of wheat flours. Journal of Cereal Science 3, 221-230.

MacRitchie, F., Lafiandra, D., 2001. Use of near-isogenic wheat lines to determine protein composition-functionality relationships. Cereal Chemistry 78, 501-506.

Maiuri, L., Ciacci, C., Ricciardelli, I., Vacca, L., Raia, V., Auricchio, S., Picard, J., Osman, M., Quaratino, S., Londei, M., 2003. Association between innate response to gliadin and activation of pathogenic T cells in coeliac disease. The Lancet 362, 30-37.

Mann, G., Allen, H., Morell, M.K., Nath, Z., Martin, P., Oliver, J., Cullis, B., Smith, A., 2005. Comparison of small-scale and large-scale extensibility of dough produced from wheat flour. Australian Journal of Agricultural Research 56, 1387-1394.

Mansur, L.M., Qualset, C.O., Kasarda, D.D., Morris, R., 1990. Effects of 'Cheyenne' chromosomes on milling and baking quality in 'Chinese Spring' wheat in relation to glutenin and gliadin storage proteins. Crop Science 30, 593-602.

Marino, C.L., Tuleen, N.A., Hart, G.E., Nelson, J.C., Sorrells, M.E., Lu, Y.H., Leroy, P., Lopes, C.R., 1996. Molecular genetic maps of the group 6 chromosomes of hexaploid wheat (Triticum aestivum L. em. Thell.). Genome 39, 359-366.

Mariotti, M., Lucisano, M., Pagani, M.A., 2006. Development of a baking procedure for the production of oat-supplemented wheat bread. International Journal of Food Science and Technology 41, 151-157.

Masci, S., Lafiandra, D., Porceddu, E., Lew, E.J.L., Tao, H.P., Kasarda, D.D., 1993. D-glutenin subunits - N-terminal squences and evidence for the presence of cysteine. Cereal Chemistry 70, 581-585.

Masci, S., Egorov, T.A., Ronchi, C., Kuzmicky, D.D., Kasarda, D.D., Lafiandra, D., 1999. Evidence for the presence of only one cysteine residue in the D-type low molecular weight subunits of wheat glutenin. Journal of Cereal Science 29, $17-25$.

Masoudi-Nejad, A., Nasuda, S., Kawabe, A., Endo, T.R., 2002. Molecular cloning, sequencing, and chromosome mapping of a $1 \mathrm{~A}$-encoded $\omega$-type prolamin sequence from wheat. Genome 45, 661-669.

Millar, S., 2006. Role of the dough mixing process in bread production. In: Heldman, D.R. (Ed.), Encyclopedia of Agricultural, Food, and Biological Engineering. Taylor \& Francis Group, London, pp. 1-4.

Mitea, C., Kooy-Winkelaar, Y.M.C., van Veelen, P.A., de Ru, A., Drijfhout, J.W., Koning, F., Dekking, L., 2008. Fine specificity of monoclonal antibodies against celiac disease-inducing peptides in the gluteome. American Journal of Clinical Nutrition 88, 1057-1066.

Molberg, Ø., Flæte, N.S., Jensen, T., Lundin, K.E.A., Arentz-Hansen, H., Anderson, O.D., Kjersti Uhlen, A., Sollid, L.M., 2003. Intestinal T-cell responses to high-molecular-weight glutenins in celiac disease. Gastroenterology 125, 337-344.

Molberg, Ø., Uhlen, A.K., Jensen, T., Flæte, N.S., Fleckenstein, B., Arentz-Hansen, H., Raki, M., Lundin, K.E.A., Sollid, L.M., 2005. Mapping of gluten T-cell epitopes in the bread wheat ancestors: Implications for celiac disease. Gastroenterology $128,393-401$

Oomah, B.D., 1983. Baking and related properties of wheat-oat composite flours. Cereal Chemistry 60, 220-225.

Payne, P.I., Corfield, K.G., Blackman, J.A., 1979. Identification of a high-molecularweight subunit of glutenin whose presence correlates with bread-making quality in wheats of related pedigree. Theoretical and Applied Genetics 55, 153-159.

Payne, P.I., Holt, L.M., Jarvis, M.G., Jackson, E.A., 1985. Two-dimensional fractionation of the endosperm proteins of bread wheat (Triticum aestivum): Biochemical and genetic studies. Cereal Chemistry 62, 319-326.

Perretant, M.R., Cadalen, T., Charmet, G., Sourdille, P., Nicolas, P., Boeuf, C. Tixier, M.H., Branlard, G., Bernard, S., 2000. QTL analysis of bread-making quality in wheat using a doubled haploid population. Theoretical and Applied Genetics 100, 1167-1175.

Popineau, Y., Cornec, M., Lefebvre, J., Marchylo, B., 1994. Influence of high $M_{\mathrm{r}}$ glutenin subunits on glutenin polymers and rheological properties of glutens and gluten subfractions of near-isogenic lines of wheat Sicco. Journal of Cereal Science 19, 231-241.

Pulido, O.M., Gillespie, Z., Zarkadas, M., Dubois, S., Vavasour, E., Rashid, M., Switzer, C., Godefroy, S.B., Steve, L.T., 2009. Chapter 6 - Introduction of oats in the diet of individuals with celiac disease: a systematic review. In: Taylor, S.L. (Ed.), Advances in Food and Nutrition Research. Academic Press, pp. 235-285.

Qi, L., Echalier, B., Friebe, B., Gill, B., 2003. Molecular characterization of a set of wheat deletion stocks for use in chromosome bin mapping of ESTs. Functional \& Integrative Genomics 3, 39-55.

Salentijn, E.M.J., Goryunova, S., Bas, N., van der Meer, I.M., van den Broeck, H.C., Bastien, T., Gilissen, L.J.W.J., Smulders, M.J.M., 2009. Tetraploid and hexaploid wheat varieties reveal large differences in expression of alpha-gliadins from homoeologous Gli-2 loci. BMC Genomics 10, 48.

Schuppan, D., Esslinger, B., Dieterich, W., 2003. Innate immunity and coeliac disease. The Lancet 362, 3-4.

Sebecic, B., Balenovic, J., 2001. Rapid ecologically acceptable method for wheat protein content determination - comparison of methods. Deutsche Lebensmittel-Rundschau 97, 221-225.

Shan, L., Molberg, Ø., Parrot, I., Hausch, F., Filiz, F., Gray, G.M., Sollid, L.M., Khosla, C., 2002. Structural basis for gluten intolerance in celiac sprue. Science 297, 2275-2279.

Shan, L., Qiao, S.W., Arentz-Hansen, H., Molberg, Ø., Gray, G.M., Sollid, L.M., Khosla, C., 2005. Identification and analysis of multivalent proteolytically resistant peptides from gluten: Implications for celiac sprue. Journal of Proteome Research 4, 1732-1741.

Shewry, P.R., Halford, N.G., 2002. Cereal seed storage proteins: structures, properties and role in grain utilization. Journal of Experimental Botany 53, 947-958.

Shewry, P.R., Miles, M.J., Tatham, A.S., 1994. The prolamin storage proteins of wheat and related cereals. Progress in Biophysics and Molecular Biology 61, 37-59.

Shewry, P.R., Tatham, A.S., Lazzeri, P., 1997. Biotechnology of wheat quality. Journal of the Science of Food and Agriculture 73, 397-406.

Singh, N.K., Shepherd, K.W., 1988. Linkage mapping of genes-controlling endosperm storage proteins in wheat. 1 . Genes on the short arms of group- 1 chromosomes. Theoretical and Applied Genetics 75, 628-641.

Singh, N.K., Donovan, R., MacRitchie, F., 1990. Use of sonification and size-exclusion high-performance liquid chromatography in the study of wheat flour proteins. II. Relative quantity of glutenin as a measure of breadmaking quality. Cerea Chemistry 67, 161-170.

Skerritt, J.H., Bekes, F., Murray, D., 1996. Isolation treatments and effects of gliadin and glutenin fractions on dough mixing properties. Cereal Chemistry 73, 644-649.

Smith, A.B., Cullis, B.R., Appels, R., Campbell, A.W., Cornish, G.B., Martin, D. Allen, H.M., 2001. The statistical analysis of quality traits in plant improvement programs with application to the mapping of milling yield in wheat. Australian Journal of Agricultural Research 52, 1207-1219.

Sollid, L.M., 2002. Coeliac disease: dissecting a complex inflammatory disorder. Nature Reviews Immunology 2, 647-655.

Song, Y., Zheng, Q., 2007. Dynamic rheological properties of wheat flour dough and proteins. Trends in Food Science \& Technology 18, 132-138.

Song, Y., Zheng, Q., 2008. Influence of gliadin removal on strain hardening of hydrated wheat gluten during equibiaxial extensional deformation. Journal of Cereal Science 48, 58-67.

Sourdille, P., Perretant, M.R., Charmet, G., Leroy, P., Gautier, M.F., Joudrier, P. Nelson, J.C., Sorrells, M.E., Bernard, M., 1996. Linkage between RFLP markers and genes affecting kernel hardness in wheat. Theoretical and Applied Genetics 93 580-586.

Spaenij-Dekking, L., Kooy-Winkelaar, Y., van Veelen, P., Drijfhout, J.W., Jonker, H. van Soest, L., Smulders, M.J.M., Bosch, D., Gilissen, L.J.W.J., Koning, F., 2005. Natural variation in toxicity of wheat: potential for selection of nontoxic varieties for celiac disease patients. Gastroenterology 129, 797-806.

Tamás, L., Shewry, P.R., 2006. Heterologous expression and protein engineering of wheat gluten proteins. Journal of Cereal Science 43, 259-274.

Tosi, P., Parker, M., Gritsch, C.S., Carzaniga, R., Martin, B., Shewry, P.R., 2009. Trafficking of storage proteins in developing grain of wheat. Journal of Experimental Botany 60, 979-991.

Uthayakumaran, S., Gras, P.W., Stoddard, F.L., Bekes, F., 1999. Effect of varying protein content and glutenin-to-gliadin ratio on the functional properties of wheat dough. Cereal Chemistry 76, 389-394.

Uthayakumaran, S., Stoddard, F.L., Gras, P.W., Bekes, F., 2000. Effects of incorporated glutenins on functional properties of wheat dough. Cereal Chemistry 77, 737-743.

Uthayakumaran, S., Tömösközi, S., Tatham, A.S., Savage, A.W.J., Gianibelli, M.C., Stoddard, F.L., Bekes, F., 2001. Effects of gliadin fractions on functional properties of wheat dough depending on molecular size and hydrophobicity. Cereal Chemistry 78, 138-141.

Vader, L.W., Kooy, Y.M.C., van Veelen, P.A., de Ru, A., Harris, D., Benckhuijsen, W. Peña, S., Mearin, L., Drijfhout, J.W., Koning, F., 2002. The gluten response in children with celiac disease is directed toward multiple gliadin and glutenin peptides. Gastroenterology 122, 1729-1737.

Van Herpen, T.W.J.M., Goryunova, S., van der Schoot, J., Mitreva, M., Salentijn, E.M.J., Vorst, O., Schenk, M., van Veelen, P., Koning, F., van Soest, L., Vosman, B. Bosch, D., Hamer, R.J., Gilissen, L.J.W.J., Smulders, M.J.M., 2006. Alpha-gliadin genes from the $\mathrm{A}, \mathrm{B}$, and $\mathrm{D}$ genomes of wheat contain different sets of celiac disease epitopes. BMC Genomics 7, 1.

Van Herpen, T.W.J.M., Riley, M., Sparks, C., Jones, H.D., Gritsch, C., Dekking, L. Hamer, R.J., Bosch, D., Salentijn, E.M.J., Smulders, M.J.M., Shewry, P.R. Gilissen, L.J.W.J., 2008. Detailed analysis of the expression of an alpha-gliadin promoter and the deposition of alpha-gliadin protein during wheat grain development. Annals of Botany 102, 331-342.

Van den Broeck, H.C., America, A.H.P., Smulders, M.J.M., Bosch, D., Hamer, R.J., Gilissen, L.J.W.J., van der Meer, I.M., 2009a. A modified extraction protoco enables detection and quantification of celiac disease-related gluten proteins from wheat. Journal of Chromatography B 877, 975-982.

Van den Broeck, H.C., van Herpen, T.J.W.M., Schuit, C., Salentijn, E.M.J., Dekking, L., Bosch, D., Hamer, R.J., Smulders, M.J.M., Gilissen, L.J.W.J., van der Meer, I.M., 2009b. Removing celiac disease-related gluten proteins from bread wheat while retaining technological properties: a study with Chinese Spring deletion lines. BMC Plant Biology 9, 41. 
Van den Broeck, H.C., Hongbing, C., Lacaze, X., Dusautoir, J.-C., Gilissen, L.J.W.J., Smulders, M.J.M. van der Meer, I.M., 2010a. In search of tetraploid wheat accessions reduced in celiac disease-related gluten epitopes. Molecular BioSystems 6, 2206-2213.

Van den Broeck, H.C., de Jong, H.C., Salentijn, E.M.J., Dekking, L., Bosch, D. Hamer, R.J., Gilissen, L.J.W.J., van der Meer, I.M., Smulders, M.J.M., 2010b. Presence of celiac disease epitopes in modern and old hexaploid wheat varieties: wheat breeding may have contributed to increased prevalence of celiac disease. Theoretical and Applied Genetics 121, 1527-1539.

Verbruggen, I.M., Veraverbeke, W.S., Delcour, J.A., 2001. Significance of LMW-GS and HMW-GS for dough extensibility: 'Addition' versus 'incorporation' protocols. Journal of Cereal Science 33, 253-260.

Wang A., Gao, L., Li, X., Zhang, Y., He, Z., Xia, X., Zhang, Y., Yan, Y., 2008. Characterization of two 1D-encoded $\omega$-gliadin subunits closely related to dough strength and pan bread-making quality in common wheat (Triticum aestivum L.). Journal of Cereal Science 47, 528-535.
Weegels, P.L., Marseille, J.P., Bosveld, P., Hamer, R.J., 1994. Large-scale separation of gliadins and their bread-making quality. Journal of Cereal Science 20, 253-264.

Weegels, P.L., Orsel, R., van de Pijpekamp, A.M., Lichtendonk, W.J., Hamer, R.J., Schofield, J.D., 1995. Functional properties of low $\mathrm{M}_{\mathrm{r}}$ wheat proteins. II. Effects on dough properties. Journal of Cereal Science 21, 117-126.

Weegels, P.L., van de Pijpekamp, A.M., Graveland, A., Hamer, R.J., Schofield, J.D., 1996. Depolymerisation and re-polymerisation of wheat glutenin during dough processing. I. Relationships between glutenin macropolymer content and quality parameters. Journal of Cereal Science 23, 103-111.

Woychik, J.H., Boundy, J.A., Dimler, R.J., 1961. Starch gel electrophoresis of wheat gluten proteins with concentrated urea. Archives of Biochemistry and Biophysics 94, 477-482.

Zhang, D., Doehlert, D.C., Moore, W.R., 1998. Rheological properties of $(1 \rightarrow 3)$, $(1 \rightarrow 4)-\beta$-D-glucans from raw, roasted, and steamed oat groats. Cereal Chemistry $75,433-438$. 